\title{
The Exploration of STEP Teaching Mode of Automation Majors
}

\author{
Xiuni $\mathrm{Xu}^{1,2}$, Li Zhao ${ }^{2}$ \\ ${ }^{1}$ College of Electrical Engineering, Longdong University, Gansu, China, 745000 \\ ${ }^{2}$ College of Automation and Electrical Engineering, Tianjin University of Technology and \\ Education, Tianjin, China, 300202
}

Keywords: automation major, STEP teaching mode, project

\begin{abstract}
STEP is short for Software, Theory, Experiment and Project. STEP teaching mode closely combines software tools, theory teaching, experiment and project practice. Theory teaching and experiment is an indispensable teaching link in most engineering courses. With the increasing variety of engineering software tools, the functions are getting stronger and stronger, and the simulation effects are becoming more and more realistic. Most of the basic courses, professional basic courses or professional courses of the automation majors have professional software matching them, which provides good conditions for the implementation of the STEP teaching mode. The STEP teaching mode takes the project as the carrier, through software tools, hands-on practice and other "learning in the doing", to improve students' ability of using the knowledge they have learned to solve practical engineering projects.
\end{abstract}

\section{Introduction}

The jobs for automation majors mainly include the research, design, manufacturing, assembly, operation, debugging, maintenance, sales and after-sales technical services of related equipment and products, which involve a wide range of industries, with many types of products and many types of work. Therefore, students need to master many skills in the teaching process. This puts forward high demands on the teachers. Teachers are required to timely absorb the experience of teaching and talent cultivation, to integrate teaching resources including open Internet teaching resources, such as MOOC, according to course content and learning effect requirements, to innovate teaching models and learning methods, such as Experiential Learning, project-based Learning, problembased Learning, inquiry-based Learning, case teaching, flipped classroom and other teaching methods.

Introduction of STEP teaching mode

Jingjun Yu, Weidong Guo and Diansheng Chen of Beihang University have proposed STEP teaching mode for engineering education. STEP is short for Software, Theory, Experiment and Project. STEP teaching mode closely combines software tools, theory teaching, experiment and project practice. Theory teaching and experiment is an indispensable teaching link in most engineering courses. The variety of engineering software tools is rich, the function is more and more powerful, the simulation effect is more and more realistic.Virtual design and simulation in the 
software environment has become an indispensable link in the entire product cycle, learning and mastering various related virtual design and simulation software has become a necessary capability for the practitioners in the engineering field. Proper implementation of STEP teaching can achieve twice the result with half the effort.

Most of the basic courses, professional basic courses or professional courses of automation majors have corresponding professional software. Software tools for some core courses of automation majors are shown in table 1 . This provides the possibility for the implementation of STEP teaching mode. In the traditional course teaching process, the project is used as a carrier to introduce software tools. It can not only use the advantages of computer software to enable students to explore and study in the simulated situation vividly, which is conducive to improving students' interest without breaking the original system of knowledge, so that students can understand and master the theoretical knowledge and acquire more operational skills faster and better. At the same time, the challenges faced by the teacher are relatively small. Moreover, in a task-driven way, the learning of software is integrated into the course teaching process, and the application is better than the simple learning software.

Table 1 Software tool for some core courses of automatic majors

\begin{tabular}{l|l}
\hline Course name & Software tools \\
\hline Circuit principle & Multisim \\
Analog electronics & SPICE \\
Digital electronics & Quartus II \\
Principle and interface technology of & Proteus +Keil C51 \\
single chip microcomputer & \\
Electrical Machinery towage & SIMULINK \\
Programmable controller & SIEMENS, Mitsubishi Corporation \\
Engineering drawing and CAD & Auto CAD \\
Power electronic technology & PLECS、MATLAB \\
The factory power supply & MCGS \\
Electric drive control system & PLECS \\
\hline
\end{tabular}

The project, which is the key for students to understand, apply what they have learned and even innovate, runs through each STEP teaching mode. The project can be derived from actual projects, real scientific research projects, or design virtual projects according to the syllabus. The actual project and real research project can be divided into several sub-projects. Sub-projects can be used as the subject of extracurricular training for students.

The sub-projects which are closely related to the teaching content can be used as the main body of the teaching content, and the sub-projects which are closely linked to the theoretical knowledge can be further merged into the field of theory teaching, with the help of the projects the main body of theory knowledge can be organically combined together, which can effectively enhance the students' overall grasp and application ability of knowledge, and can attract the students' learning interest.

Although in STEP teaching mode, the project teaching is integrated, but it is not equivalent to the project teaching. Project-based teaching is a student-centered activity teaching method jointly established by professor Katz, an American child educator, and professor Chad, a Canadian child educator. It combines inquiry teaching method, task-driven teaching method and case teaching method, integrates the knowledge and skills required by professional job groups, and forms targeted projects, and complete teaching tasks by implementing projects. The advantage of project-based teaching lies in that it can effectively improve students' knowledge reorganization, application ability and systematic practice ability. The disadvantage is that it is easy to destroy the integrity and sequence of theoretical knowledge system, leading to the fragmentation of students' knowledge. 
Knowledge system is of great significance for students to master systematic knowledge and further study. In STEP teaching mode, the project is not the subject of knowledge, but an effective case for students to master knowledge. It still emphasizes the importance of knowledge system in course teaching, inherits the advantages of project-based teaching and overcomes its disadvantages.

The STEP teaching mode is to improve student' ability to solve practical engineering projects through software tools and hands-on practice. The effective improvement of students' engineering practice ability is bound to be recognized and favored by employers. With the help of powerful software simulation tools, students can complete the project implementation process that is hard to reach in examination papers or course reports. However, the diversity of STEP teaching mode, diversified teaching links and teaching methods require teachers and students to invest more in time, energy and even resources.

\section{Comparison between STEP and CDIO}

In order to balance theoretical learning and practical ability in engineering education, four universities, including MIT and royal Swedish institute of technology, established the concept of CDIO engineering education after four years of exploration and research, proposed the education model of CDIO engineering, and established an international cooperation organization named CDIO.

CDIO is the abbreviation of Conceive, Design, Implement and Operation. These four words Conception-Design-Implementation-Operation are chosen because they cover most of the major professional activities of engineers. Conception refers to the systematic conception and thinking, including the overall process of determining the customers' needs and considering technology, enterprise strategy and relevant regulations, which requires creativity. Design refers to understanding the users' expectations, needs and motivations first, and then transforming them into products, including design, drawings and methods and calculations that describe product, process and system implementation, in which specialized skills are required. Implement refers to the complete transition process from design to product, including software programming, hardware manufacturing, testing and verification. Operation refers to the process after product manufacturing, including system maintenance, protection, transformation, recycling and scrapping. CDIO engineering education model emphasizes on cultivating students' comprehensive practical ability and innovation consciousness, encourages students to learn independently and experience, pays attention to the cultivation of communication ability and team cooperation consciousness, and it is adapted to the social and economic development environment, which has been recognized by education international higher engineering. Since it was introduced to China in 2005, it has also achieved good results.

First of all, CDIO engineering education mode constructs the course system from the vertical level according to the product realization process, while STEP builds on the horizontal level through methods and means. Following the CDIO syllabus and 12 standards, Setting up a comprehensive curriculum system (including introduction course, subject course, professional course and comprehensive practice project, etc.) can achieve the required training objectives. Because of the relevance, advanced and expansibility of the knowledge structure between courses in engineering majors or disciplines, STEP can also effectively build the curriculum system at the professional level, especially supporting the cultivation of the ability to solve complex engineering problems. The subtle difference between the two is that CDIO is more macro while STEP is more micro. Therefore, STEP is more operable.

Secondly, both CDIO and STEP attach importance to process management and rely on the support of the internal quality assurance system. The diversification of teaching links and teaching 
methods must pay attention to process management and pay close attention to the construction of internal quality assurance system. Both models require teachers and students more investment in time, energy and even resources.

Thirdly, both CDIO and STEP attach importance to the "export" characteristics of students, that is, to improve students' ability to solve practical engineering projects through "Learning by doing" such as software tools, hands-on practice. The effective improvement of students' engineering practice ability is bound to be recognized and favored by employers.

\section{STEP teaching mode teaching design}

On the basis of in-depth analysis of students' learning characteristics and the real needs of enterprises in the field of professional technology of automation, taking the project as the carrier, taking the software as the tool, taking the theoretical teaching and experimental teaching as the mainline, integrating and optimizing the teaching content, exploring practical teaching plans, a higher level of "teaching, learning, doing" integrated STEP teaching model teaching design is achieved.

Taking "digital circuit" the basic course of automation specialty as an example, digital circuit is a basic course, and it is also one of the ideal courses for engineering thinking training and engineering training for students. Through experiments, software simulation and simple hands-on construction, students will be trained to master the analysis and design capabilities of digital circuits and their systems, and attention should be paid on the cultivation of students' innovative design capabilities.

The technical route of digital circuit STEP teaching mode is shown in Figure 1.

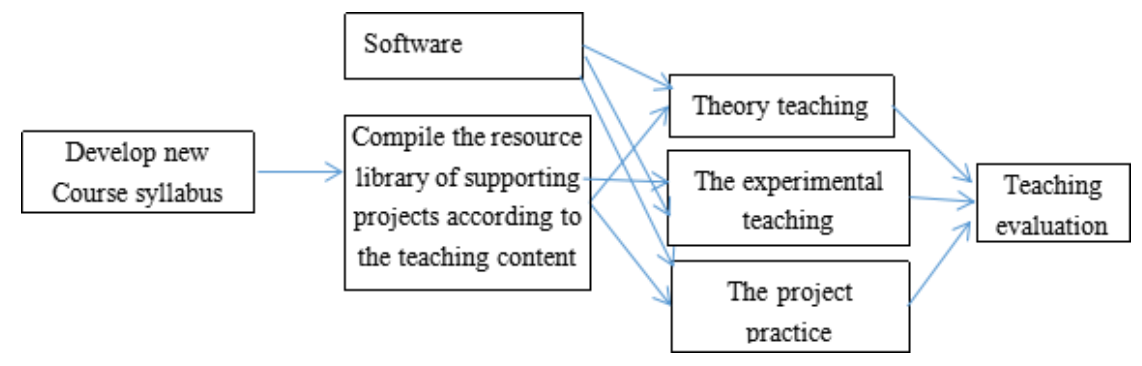

Figure 1 The technical route of digital circuit STEP teaching mode

The specific route is as follows:(1) Develop a new course syllabus and define the STEP teaching mode and its corresponding assessment proportion. STEP teaching mode is adopted to improve students' ability to solve engineering practice problems. The teaching links include classroom teaching + experimental teaching + project practice. Assessment method: usual scores (10 points) + experimental scores (10 points) + project practice (10 points) + final scores (70 points). (2) Compile the project resource library that is compatible with the teaching content. In order to better cooperate with STEP teaching and achieve the expected teaching effect, the project resource library should be compiled to match the teaching content. The prepared project should complement the knowledge and ability with the regular assignments and final exams. (3) Fully introduce software in the teaching process. In the process of theory teaching, experiment teaching and project practice, software such as Multisim can be used as an important tool for virtual simulation and analysis. (4) Create a multi-level experimental teaching system and an open teaching environment in the experimental teaching part. On the one hand, combining experiments with cognition, validation, comprehensiveness and independent innovation design \& making. On the other hand, combining experiments of analytical and research and innovative design, which can provide students with open space and sufficient experimental resources ${ }^{[5]}$. 
Take the digital electronic clock project as an example to carry on the comprehensive reform to the teaching content, method and teaching mode, in order to make the theoretical and experimental courses integrated. The block diagram of digital electronic clock circuit system is shown in Figure 2. This teaching project almost covers the core knowledge points in the theoretical courses of digital electronic technology, such as analysis and design of combination circuits, analysis and design of sequential circuits, trigger, generation and transformation of pulse waveform, etc. The task decomposition of digital electronic clock system is shown in Table 1.The second/minute counter and display simulation figure are shown in figure 3.

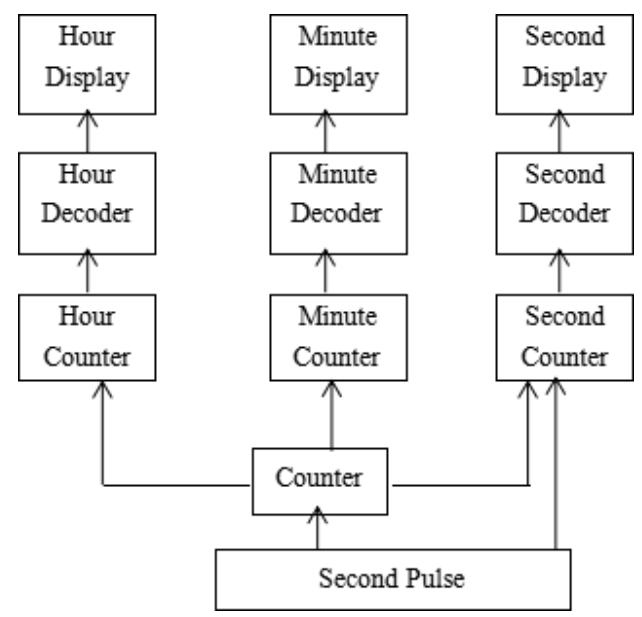

Figure 2 The block diagram of digital electronic clock circuit system

Table 1 The task decomposition of digital electronic clock system

\begin{tabular}{|c|c|c|c|c|}
\hline Decomposition & Task & Knowledge point & Implementation plan & Results \\
\hline 1 & $\begin{array}{l}\text { Form the pulse } \\
\text { waveform with } \\
\text { oscillating } \\
\text { frequency f as } \\
1 \mathrm{KHz}\end{array}$ & A 555 timer & $\begin{array}{c}\text { A } 555 \text { timer is used to form a } \\
\text { multivibrator }\end{array}$ & $\begin{array}{c}\text { Generate pulse } \\
\text { waveform of } 1 \mathrm{KHz}\end{array}$ \\
\hline 2 & $\begin{array}{l}\text { Frequency division, } \\
\text { second pulse } \\
\text { generation }\end{array}$ & Divider & $\begin{array}{l}\text { Three pieces of the scale } \\
\text { integrated circuit counter } \\
\text { 74LS90 is adopted }\end{array}$ & $\begin{array}{l}\text { Get the required } \\
\text { second pulse signal }\end{array}$ \\
\hline 3 & Timing circuit & RS flip-flop anti-jitters & Switch and RS flip-flop & $\begin{array}{l}\text { Realize hour, minute } \\
\text { timing }\end{array}$ \\
\hline 4 & $\begin{array}{l}\text { Two } 60 \text { - decimal } \\
\text { counters are } \\
\text { designed to be used } \\
\text { as second and } \\
\text { minute counters } \\
\text { respectively }\end{array}$ & $\begin{array}{c}\text { The integrated counter } \\
\text { constitutes an arbitrary } \\
\text { decimal counter }\end{array}$ & $\begin{array}{l}\text { Using } 74 \mathrm{X} 160 \text { to achieve } 60 \text { - } \\
\text { decimal counter }\end{array}$ & $\begin{array}{l}\text { Implement } 60 \text { - } \\
\text { decimal counter }\end{array}$ \\
\hline 5 & $\begin{array}{l}\text { Design a 24-base } \\
\text { counter time } \\
\text { counter }\end{array}$ & $\begin{array}{l}\text { The integrated counter } \\
\text { constitutes an arbitrary } \\
\text { decimal counter }\end{array}$ & $\begin{array}{l}\text { Using } 74 X 160 \text { to achieve } 24- \\
\text { decimal counter }\end{array}$ & $\begin{array}{l}\text { Implement } 24 \text { - } \\
\text { decimal counter }\end{array}$ \\
\hline 6 & Display digit & $\begin{array}{l}\text { Decoding drive and } \\
\text { digital tube display }\end{array}$ & $\begin{array}{l}\text { CD4511 and the common } \\
\text { cathode digital tube are } \\
\text { adopted }\end{array}$ & $\begin{array}{l}\text { Realize seconds, } \\
\text { minutes, time display }\end{array}$ \\
\hline 7 & $\begin{array}{l}\text { Extension } \\
\text { requirement: } \\
\text { realize the time } \\
\text { reporting } \\
\text { requirement of the } \\
\text { whole point }\end{array}$ & Student self-drafting & Student self-drafting & Hourly chime \\
\hline
\end{tabular}




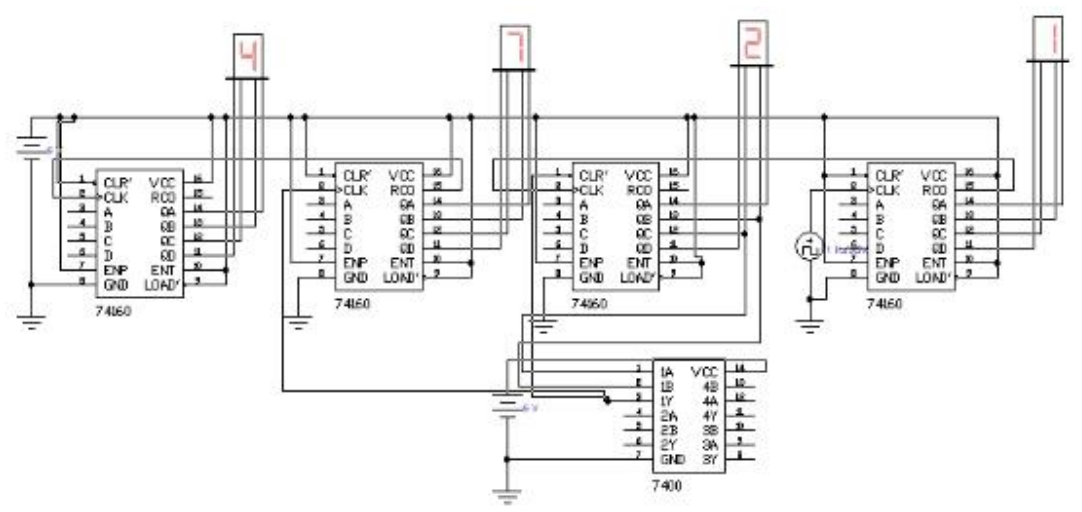

Figure 3 The second/minute counter and display simulation figure

\section{Summary and outlook}

STEP teaching mode emphasizes the organic integration of theory teaching and experiment teaching, software tools and project practice. It emphasizes the relevance of knowledge system, the level of project setting and the seamless connection of different software tools. STEP teaching model puts forward higher requirements for teachers and teaching teams. It is mainly reflected in the following aspects: (1)Teachers and teaching teams should have advanced and mature teaching concepts. (2) Sufficient teaching resources and funds (3)Teaching small class (4)Strong support of teachers and teams is needed to ensure the integrity, leading-edge and scalability of the project only when a large proportion of teaching and research teachers, especially professors, participate in the setting, organization and implementation of the project. (5) The sense of responsibility and organizational ability of the teachers, especially the head of the teaching team, is an important guarantee for the success of STEP teaching. STEP teaching will undoubtedly bring multiple workload to teachers. Only with a strong sense of responsibility can the teaching process be coordinated and orderly, the teaching evaluation is fair and just, and the teaching effect is expected.

\section{References}

[1] Yu Jingjun, Guo Weidong, Chen Diansheng. STEP teaching model for engineering education [J]. Research on higher engineering education, 2017(4).

[2] Gu Peihua et al.CDIO in China (on) [J]. Education research of higher engineering, 2012(3).

[3] Yu Jingjun et al. Improvement of system carving contents and innovative forms to create high-quality products [J]. Education research of advanced engineering, 2013 supplement.

[4] Chen Long, Qie Xiaomei, Ma Xuetiao. Comprehensive virtual simulation experiment teaching reform of digital electronic technology [J]. Laboratory research and exploration, 2017(5).

[5] Deng Yonghe. Exploration of training teaching system of excellent engineers' independent learning ability in fundamental physics experiments [J]. Journal of hunan institute of engineering: social science edition, 2011. 